KEMAS 15 (3) (2020) xxx-xxx
Jurnal Kesehatan Masyarakat

\title{
Knowledge and Motivation with Safe Behavior of Informal Sector Female Worker
}

\author{
Suryanto ${ }^{\bowtie}$, Damairia Hayu Parmasari \\ Faculty of Health Sciences, Jenderal Soedirman University, Indonesia
}

\begin{tabular}{l} 
Article Info \\
\hline Article History: \\
Submitted September 2019 \\
Accepted January 2020 \\
Published March 2020 \\
\hline Keywords: \\
Safe Behavior, Informal \\
Sector, Female Worker \\
\hline DOI \\
https://doi.org/10.15294/ \\
kemas.v15i3.21123
\end{tabular}

\begin{abstract}
One of the informal sectors that absorbs labors in Indonesia is informal work in the household. This job can absorb workers but having health problems and safety risks if they do not apply safe behavior. Factors influence safe behavior are knowledge and motivation. This study is to determine the relationship of knowledge and motivation to safe behavior in the informal sector female workers. This research is cross-sectional quantitative observational design. The sample are 45 workers. The independent variables are knowledge and motivation. The dependent variable is safe behavior. The instrument is questionnaire. Research data is analyzed by chi-square. The result of the study showed no significant relationship between knowledge and safe behavior ( $\mathrm{p}=0,496>0,05)$. Chi square analysis showed there is no significant relationship between motivation and safe behavior with $\mathrm{p}=0.545>0.05$. This study gives insignificant results, so the next researcher can discuss more factors that influence safe behavior with different research methods so that they can enrich new findings in the field of Occupational Safety and Health, both of which later give significant or insignificant results. Therefore, this research is important to be published. The conclusion from the study is no significant relationship between knowledge and motivation to safe behavior.
\end{abstract}

\section{Introduction}

Indonesia as a developing Asia has a major problem that is empowering people who do not have higher education and trained skills to still be able to contribute to the realization of national development. This will have an impact on Indonesia's large population will not be a burden of development but become the capital. The informal sector can be a means of developing human resources for workers who are not trained to work and improve skills before entering employment in the formal sector (Badan Perencanaan Pembangunan Nasional. 2009). According to Hart (1973) the informal sector provides opportunities for groups of women. displaced victims and others to do work that does not require high education and managerial skills. The informal sector provides space for small communities to survive and not become unemployed (Pitoyo. 2007).
Based on data from the Badan Pusat Statistik (Central Statistics Agency) (2018). it shows that 53.09 million people work in the formal sector and 73.98 million people work in the informal sector. The data shows that the informal sector has the role of absorbing labor in Indonesia. One type of informal sector that absorbs a lot of labor in Indonesia is in the domestic environment. such as culinary (food). laundry. and boarding-lodging businesses. These jobs can absorb labor. especially women. However. they also has risks that can cause health problems and occupational safety risks. Work in the domestic environment has hazards such as electric shock. knife-sliced hands. musculoskeletal disorders. vision. skin. splashing oil during cooking. gas cylinder explosion. and falling. Health and safety risks experienced by women workers in the domestic environment can interfere work productivity 
(Kementerian Kesehatan RI. 2019).

Occupational health and safety problems of female workers in the domestic environment can be caused by several factors. Heinrich (1980) said that the occupational health and safety disorders of workers are affected by unsafe act (unsafe work behavior) and unsafe condition (unsafe work environment). Unsafe work behaviors that can cause health problems and safety risks are affected by knowledge about health and safety in the workplace environment (Notoatmodjo 2003).

Safe behavior carried out by informal sector female workers in the domestic environment can be affected by workers' knowledge and motivation. Green (1980) says that increasing knowledge does not always lead to behavior change. but knowledge is very important given before individuals take action. A person's actions will be in accordance with knowledge if the individual receives good cues from the knowledge received so that the person acts accordingly. Agiviana and Djastuti (2015) said that there is a significant relation between knowledge and safety behavior among workers in PT Mulia Glass Contaniner Division. In addition. the results of research by Dzulfiqar and Handayani (2016) showed that there is a significant relation between knowledge and safety behavior among welding workshop workers in the Pejompongan area of Bendungan Hilir. Central Jakarta. Another factor that affects safe behavior is work motivation. Geller and Scott (2005) said that motivation is a factor that can affect the emergence of safe behavior. Research by Huda et al. (2016) shoed that there is a significant relation between work motivation and worker safe behavior throughout the Bogor SPBE. Employees who have high work motivation will behave safely while employees who have poor work motivation will act unsafe. This is supported by the results of research by Fara et al. (2017) which showed that there is a significant relation between motivation for safe behavior and safe behavior among civilian contractor workers at PT Indonesia Power Up Semarang. In addition. Karyani (2005) said that there is a significant relation between work motivation with the safe behavior of workers at Schlumberger Indonesia.

The results of preliminary observations made by researcher indicate that the Karangwangkal Village. North Purwokerto is an area that has workers in the informal sector. Informal sector workers are housewives who work in their own homes by opening a variety of businesses such as culinary. grocery shop. selling gasoline. laundry. and boarding houses. All jobs in the informal sector are inseparable from occupational safety risks. This is in accordance with Yusida et al. (2017) which stated that occupational safety and health are influenced by potential hazards and risks posed by materials. use of machinery. tools. processes. ways of working. people and the environment. In addition. female workers in Karangwangka. Northl Purwokerto have never received counseling on occupational health and safety. Based on that research about "Relation between knowledge and motivation with safe behavior of informal sector female worker " needs to be done. This study objective is to determine the relation of knowledge and work motivation with safe behavior of informal sector female workers.

\section{Method}

This type of research is an observational quantitative study with a cross sectional design. It was conducted in Karangwangkal. North Purwokerto. The time was June 29. 2019. The population was housewives working in informal sector in Karangwangkal. North Purwokerto. The sample was housewives who meet the sample inclusion criteria that was willing to be respondents of the research and classified as productive age for work that is 15-64 years. women who switch professions as formal sector workers. Based on these criterias. 45 research samples were obtained. The independent variables were work knowledge and motivation. while the dependent variable was safe behavior.

The data taken includes data on knowledge motivation. and safe behavior. It was obtained through questionnaires distributed to respondents. Each question in the questionnaire had 4 answer choices. The correct answer was given a value of 1 and the wrong answer was given a value of 0 . The thing measured in the safe behavior knowledge questionnaire was the respondent's understanding of safe behavior. Standard Operating Procedures (SOP). the importance of using PPE. examples of safe 
and unsafe actions. work accident prevention and controlling work accidents. What was measured in the motivation questionnaire were the motivation goal. how to increase motivation. and how to maintain safe behavior motivation. What was measured in the safe behavior questionnaire was the real action that the respondent took while working as if he was already wearing PPE at work. not doing dangerous actions while working. and doing work according to SOP.

Furthermore.thedatatakenwasprocessed using SPSS 16 software. After obtaining the total value from each questionnaire. the total value is categorized. The questionnaire was tested for validity to test the validity of the questions in the questionnaire. Validity test is conducted on subjects that were not used for research but had the same characteristics as the research respondents. Validity test was done by using the Pearson Correlation test. If the $\mathrm{p}$ value of the questions in the questionnaire is $<0.05$. then the question is declared valid. If the $p$ value of the questions in the questionnaire $>0.05$. then the question is declared invalid. If there are invalid questions. then the questions are not included in the questionnaire. The reliability test was performed by comparing the Cronbach alpha value with the value of $r$. If the value of alpha> 0.6 then the data obtained is declared reliable. Validity test was conducted for respondents who did not participate in the study but had the same characteristics as the research respondents. The variables were K3 knowledge. work motivation and safe behavior. Each variable was categorized into good and poor. The good category if it had a total value (correct answer score) 5-7. while the poor if it had the total value (correct answer score) $0-4$. In addition. the data were analyzed by univariate analysis such as mean (mean). maximum value. minimum value. and standard deviation. Bivariate analysis was performed to examine the relationship of each independent and dependent variable. Bivariate analysis was performed using the Chi Square test. The relationship between independent and dependent variables is said to be significant if it has a significance value $(\mathrm{p})<0.05$. In addition. to determine the strength of the relation between safety knowledge and occupational health (K3) and work motivation with safe behavior was done by looking at the value of $r$. The following are interpretations of the value of $r$ to assess the strength of the relation between the independent and dependent variables:

Table 1. Interpretation of $r$ Value Correlation Coefficient

\begin{tabular}{ll}
\hline Coefficient Interval & Relation \\
\hline $0.00-0.199$ & Very low \\
$0.20-0.399$ & Low \\
$0.40-0.599$ & Medium \\
$0.60-0.799$ & High \\
$0.80-1.000$ & Very high \\
\hline
\end{tabular}

Furthermore. to determine the most dominant factor contributing to safe behavior. a multivariate analysis using logistic regression test was performed. The results of the bivariate analysis which had a $p$ value $<0.25$ were included in the logistic regression analysis.

\section{Result and Discussion}

Female workers in Karangwangkal. North Purwokerto. mostly work in the informal sector. They work in their household environment by opening a culinary business (food). laundry. and boarding houses. Based on the results of observations and interviews conducted by researchers. quite a lot of informal sector female workers still do not understand about Occupational Safety and Health (K3) or safe behavior (safe actions). The following were some of the unsafe actions taken by women workers in the informal sector in Karangwangkal.

Based on researchers' observations. workers still had not done work in accordance with the Standard Operating Procedure (SOP). According toSucietal.(2012).SOP isa systematic work procedure on work implementation in the workplace in order to reduce the risk of work accidents. SOP is used as a guide for workers to carry out work. Female workers in the informal sector in Karangwangkal claimed to have known about SOPs. but they had not implemented SOPs in their work because there were no available facilities and infrastructure to conduct safe behavior and still assumed that unsafe actions taken so far while working would not cause danger. Women in the informal sector who have a culinary business said that 
Table 2. Unsafe Actions of Female Workers in Informal Sector in Karangwangkal, North Purwokerto

\begin{tabular}{|c|c|}
\hline Kind of Business & Unsafe Act \\
\hline \multirow{8}{*}{$\begin{array}{l}\text { Culinary Business } \\
\text { (food) }\end{array}$} & Using poor lighting sources when cooking \\
\hline & $\begin{array}{l}\text { Not storing food ingredients properly (food ingredients are not covered } \\
\text { with a food hood) }\end{array}$ \\
\hline & $\begin{array}{l}\text { Has not provided a special container for work equipment (knives and } \\
\text { scissors that are not placed in a special container) }\end{array}$ \\
\hline & Using single electrical terminal for multiple equipment \\
\hline & $\begin{array}{l}\text { Laying of combustible material close to the heat source (Laying gasoline } \\
\text { selling places adjacent to cooking places where there is a stove) }\end{array}$ \\
\hline & Do not use aprons when cooking \\
\hline & $\begin{array}{l}\text { Repetition, static and not ergonomic (Sweeping the floor, cleaning the } \\
\text { floor, standing while cooking for a long time, refining the seasoning when } \\
\text { cooking) }\end{array}$ \\
\hline & $\begin{array}{l}\text { Do not use strong equipment handles (Use a handle of a teapot, pot or pan } \\
\text { that is not strong enough to withstand the load) }\end{array}$ \\
\hline \multirow{3}{*}{ Laundry } & $\begin{array}{l}\text { Put dangerous materials or items near the reach of children (Put detergent } \\
\text { and soap on the floor) }\end{array}$ \\
\hline & Do not wear PPE (gloves and masks) \\
\hline & $\begin{array}{l}\text { Repetition and static movements during the process of washing or drying } \\
\text { clothes (Bend, sit, stand for a long time) }\end{array}$ \\
\hline \multirow{4}{*}{ Boarding House } & $\begin{array}{l}\text { Clothes drying on the } 2 \text { nd floor that has no security around it creating the } \\
\text { risk of falling from above }\end{array}$ \\
\hline & Boarding kitchen that is not cleaned after cooking so it looks dirty \\
\hline & Slippery floor \\
\hline & The fridge has never been cleaned so it looks dirty \\
\hline
\end{tabular}

Source: Primary Data, 2019

they did not use an apron because they did not have one. In addition. they considered wearing apron was uncomfortable while working. Informal laundry sector workers expressed the same thing where wearing PPE during the process of washing clothes would only make it uncomfortable and prolong work completion. Workers in the informal culinary and laundry sector also assumed that the repetitive and static movements while working would not cause health problems or dangerous diseases so they kept doing their work without being compensated by exercises (sports) to neutralize muscles fatique. Workers in the informal sector boarding house claimed not to have enough time and energy to clean the kitchen and the equipment inside. In addition. informal sector boarding house workers do not employ workers in their boarding houses because of limited funds.

Based on the data in Table 3. the age of most respondents was 26-35 years as many as 16 people (35.56\%). Respondents were at least aged between 56-65 years. namely 3 workers (6.67\%). Informal sector female workers in Karangwangkal work by opening a culinary business. boarding houses. and laundry. The number of workers who opened a culinary business was 20 (44.44\%). laundry was 17 people $(37.78 \%)$. and boarding house was 8 people $(17.78 \%)$. The education of female workers in the informal sector in Karangwangkal is elementary through S1. The number of workers with elementary-junior high school education 
Table 3. Overview of Characteristics of Informal Sector Female Workers in Karangwangkal, North Purwokerto

\begin{tabular}{llll}
\hline Characteristics & Category & Numbers (N) & Percentage (\%) \\
\hline \multirow{4}{*}{ Age } & Early Adult (26-35) & 16 & 35.56 \\
& Late Adult (36-45) & 12 & 26.66 \\
& Early elderly (46-55) & 14 & 31.11 \\
\multirow{3}{*}{ Sector } & Late elderly (56-65) & 3 & 6.67 \\
& Culinary business & 20 & 44.44 \\
& Boarding house & 8 & 17.78 \\
Education & Laundry & 17 & 37.78 \\
& Elementary (SD-SMP) & 16 & 35.56 \\
& Mid education (SMA/SMK) & 24 & 53.33 \\
\hline
\end{tabular}

Source: Primary Data, 2019

was 16 people (35.56\%). high school as many as 24 people (53.33\%). and D1-S1 were 5 people $(11.11 \%)$.

Characteristics of respondents consisted of age. occupation. education. and years of service. Workers were mostly years old (\%). work as (\%). have education (\%). and have years of service $(\%)$.

The majority of female workers have a good level of knowledge which was 34 people (75.6\%). In addition. as many as 11 workers have poor levels of knowledge (24.4\%). Knowledge can be obtained from the experience or information of others. Knowledge is the result obtained after someone senses (Notoatmodjo. 2010). The work experience of female workers in the informal sector in Karangwangkal is obtained from a relatively long work period. There are still workers who have poor knowledge due to some workers who had not gotten information from others or counseling about Occupational Health and Safety (K3) and safe behavior. Workers have never gotten posters. leaflets. or handouts about K3 and safe behavior. This is the reason why most informal sector workers do not have good knowledge about safe behavior. This is in line with Zatalini and Wulandari (2018) who said that counseling with discussion methods. posters. and videos can increase knowledge about sexually transmitted diseases in street children. The results of the Shapiro Wilk test and T-Test showed that there were significant differences about the knowledge of sexually transmitted diseases in street children before and after counseling. In addition. Hapsari (2013) said that educational media such as banners and posters can increase workers' knowledge about risks and hazards in the workplace. Fatima (2015) said that there was a significant change in the level of knowledge in students after an intervention in the form of promoting balanced nutrition with media posters. videos. and nutrition quartet games. This is also in line with Wibowo and Suryani (2013) who said that there is a significant effect on the health promotion of audio-visual methods and pocket books on increasing knowledge of MSG usage among housewives. Sary's research (2010) showed that there is a significant relation between pre-intervention and post-intervention group knowledge of Universitas Indonesia employees before and after health promotion in the workplace.

Health promotion has an important role in the framework of community empowerment. Communities gain learning from. by and with the surrounding environment in order to be able to take proper help and action against themselves in the health sector (Fitriani. 2011). Health promotion requires the media so that the goals to be delivered to the target can be conveyed. According to the Indonesian Ministry of Health (2011). the targets of health promotion are primary. secondary and tertiary targets. Primary targets are patients. healthy 
individuals and families. Secondary targets are religious leaders. traditional leaders. health workers. government officials and the mass media. Tertiary targets are policy makers. In this study the target is the primary target (individuals or women who work as informal sector workers). The media used as health promotion are lectures. printed media and audio visual media. Both audio-visual and printed media have their advantages and disadvantages (Notoatmodjo. 2010). Audio visual methods can be done with power points. videos. games. and discussions. The printing method can use a booklet. poster or hand out.

Female workers who had good safe behavior motivation were 21 persons (46.7\%) and ones who had poor safe behavior motivation were 24 workers (53.3\%). Notoatmodjo (2012) said that motivation is a stimulus for someone to be able to do a good job. including acting safely when working. There are various factors that can affect individual motivation such as feeling satisfied with work. career. recognition. responsibility and intellect (Sialagan. 2008). Munandar (2001) said that there is a way to increase work motivation by being firm. Workers are given a compulsion or threat so that they cannot avoid the work and responsibilities given. for example is when a company or institution wants to enforce discipline in work then workers are required to always arrive on time. Workers who do not arrive on time are then given sanctions (punishment). Besides being firm. increasing work motivation can be done by providing meaningful goals. This is done by giving rewards (awards). Nawawi (2002) says that reward is an effort to foster a feeling of being recognized in the work environment. compensation. and relationships with other workers. Rewards do not only come from outside the employee. but rewards can come from within a person such as a sense of pride in achievement. happy when work is completed. and autonomy (freedom to do work without close supervision). Reward from the workplace can be in the form of promotion. bonus. or the opportunity to repay a home that is not burdensome. Mangkunegara (2005) said that rewards in the form of cash greatly affect employee work motivation. Rewards in the form of cash can increase employee motivation so productivity increases. Therefore. companies and institutions need to make budget plans for rewards in the form of it.

Quite large number of poor motivations for safe behavior among gemale workers in the informal sector in Karangwangkal are allegedly caused by the absence of rewards and punishments. According to the Hierarchy of Needs Abraham Maslow said that workers behave and work to meet a variety of needs namely physical and biological needs (clothing. food. shelter). the need for security. social needs (social interaction and can be accepted in the environment he lives). needs for appreciation. and the need for self-actualization (utilizing the ability and skills to excel and achieve selfsatisfaction). Reward is very important in motivating workers' performance so that they are more qualified and responsible with the work provided (Febrianti and Musadieq. 2014). In addition to reward. punishment also has the same purpose as reward. Mangkunegara and Anwar (2009) said that punishment is an effort to improve employee performance. maintain regulations. and give lessons to deviations committed by workers. Punishment will shape workers' disciplinary behavior towards the rules and have a deterrent effect on workers who violate them so that workers do not repeat the same actions again. Suryadilaga et al. (2016) showed that reward and punishment contributed $57.4 \%$ to the performance of employees at PT Telkom Indonesia Malang of East Java South Region.

Female workers who had good safe behavior were 38 workers $(84.4 \%)$. while 7 workers (15.6\%) had poor safe behavior. The difference in the number of workers who have good and bad safe behavior is caused by a variety of factors. Green (1980) said that a person's behavior is formed by 3 factors. namely predisposing factors. enabling factors. and reinforcing factors. Predisposing factors are factors that precede behavior such as knowledge. attitudes. perceptions. values. beliefs. and demographics. Enabling factors are external factors that enable the formation of behavior such as infrastructure. regulations and resources. Reinforcing factors are the factors that determine a behavior to get support such as coworkers. supervisors. rewards. punishment. 
Table 5. Results of Bivariate Knowledge Analysis with Safe Behavior of Informal Sector Female Workers in Karangwangkal, Purwokerto Utara

\begin{tabular}{llllllll}
\hline & \multicolumn{2}{l}{ Safe Behavior } & & & & & \\
Knowledge & $\begin{array}{l}\text { Good } \\
\mathrm{N}\end{array}$ & $\begin{array}{l}\text { Percentage } \\
(\%)\end{array}$ & $\mathrm{N}$ & Percentage (\%) & Total & Sig (p) & $\begin{array}{l}\text { Coefficion } \\
\text { (r) }\end{array}$ \\
\hline Good & 6 & 13,3 & 28 & 62,2 & 34 & & \\
Poor & 1 & 2,3 & 10 & 22,2 & 11 & 0,496 & 0,463 \\
Total & 7 & 15,6 & 38 & 84,4 & 45 & & \\
\hline
\end{tabular}

Saource: Primary Data, 2019

leadership and family. In addition to the Green Theory. Ramsey's Theory also explains the factors that influence unsafe actions carried out by someone. Ramsey said that the factors affecting unsafe actions are perception. cognitive (cognition). decision making and ability. Observation is the first stage for someone to observe danger. A person's ability to observe danger is influenced by sensory skills. alertness. and perception. Cognitive is the stage where someone can observe the danger but someone has not taken action on the danger seen. Cognitive stage is influenced by memory. experience. and training. Decision making is the stage where someone takes action against danger or something that is not safe. Decision making is strongly influenced by experience. knowledge. attitudes. and motivation. Ability is the stage where someone is able to take action against danger or risk. Decision making will not occur if someone does not have the ability to make decisions. Ability is affected by physical. physiological. and psychomotor conditions (Suizer. 1999).

In addition to Green and Ramsey's Theory which explains the factors that influence unsafe actions or behaviors. Reason (1997) said that organization is the main factor driving unsafe actions. Organizations can encourage the emergence of insecure environments that cause unsafe actions. One concrete example of organizational factors that trigger unsafe actions can be seen in construction project work such as work targets. working hours. inadequate equipment. lack of training and safety supervision. Organizational factors such as company policies that do not provide adequate facilities for work safety. supervision. and training can trigger violations of Standard
Operating Procedures (SOP) at work so as to cause hazards and work accidents. Therefore. there must be a synergy between workers and company management to be aware of safe actions and safe working environment conditions to prevent work accidents.

Table 5 shows that the correlation between knowledge and safe behavior is 0.463 . This shows that there is a sufficient correlation between knowledge and safe behavior. The analysis shows that there is no relation between knowledge and safe behavior with a value of $p=0.496>0.05$. The absence of a relation between knowledge and safe behavior is thought to be caused by respondents who have good knowledge and do not have the awareness to practice the knowledge they have in practice when working. This is supported by Bloom's theory which says that a person's knowledge has several levels consisting of (1) Know. namely recalling something that has been seen or observed (2) Understanding is the process of interpreting objects that have already known correctly (3) Application is to reuse the understanding of an object in other circumstances (4) Analysis is the ability of a person to describe or separate then connect the components that exist in a case (5) Synthesis is the ability to summarize or place the knowledge possessed in a logical arrangement (6) Evaluation is the process of justification or assessment of a particular object. The level of knowledge possessed by female workers in the informal sector in Karangwangkal has only reached the level of undestanding. The level of knowledge of workers regarding safe behavior has not reached the application level. Workers do not yet have the awareness to put into practice the real knowledge they already have in 
the case at work. This is in line with the research of Nasrullah and Suwandi (2014) which stated that there is no meaningful relation between the level of safe behavior knowledge with safe behavior actions in 41 workers in the western assembly of PT XYZ. In addition. Halimah (2010) said that there was no significant relation between the level of knowledge and safe behavior.

Good knowledge does not directly make workers have good safe behavior. This is in line with research by Annishia (2011) which showed that construction workers who have good knowledge keep doing unsafe actions when working. Helliyanti's research (2009) showed that there is no significant relation between unsafe behavior and employee knowledge. This is in line with Retnani and Ardyanto (2013) who said that increasing knowledge has no significant effect on safe behavior in workers at PT Pupuk Kalimanatan Timur. Knowledge is a factor needed to change someone's behavior. but it is not strong enough for someone to behave in accordance with the knowledge they have (Green. 1980). Reason (1997) also said that workers should have awareness of hazards and risks in the workplace to minimize workplace accidents. In addition. workers must also carry out work in accordance with their obligations and responsibilities. obeying existing regulations and procedures.

Fuadi et al. (2016) said that there was no relation between knowledge and community attitudes in preventing leptospirosis in Pabelan Village. Kartasura District. Sukoharjo Regency. The insignificant relation between knowledge and attitude is caused by attitudes that are heavily influenced by various factors such as personal experience. the influence of others. or environmental culture (Azwar. 2011). The knowledge of female workers in the informal sector in Karangwangkal needs to be improved so that they are better able to respond and behave safely in order to realize Occupational Health and Safety(K3).

Insignificant research results between knowledge and actual implementation in a job were also shown by nurses and midwives at the health center of Isfahan University. Iran. The results showed that $57 \%$ of respondents consisted of nurses and midwives had poor knowledge. causing an insignificant relation between the knowledge of HIV held by nurses and midwives to the practice of providing good care to HIV patients in Iranian hospitals (Khorvash et al. . 2014). Nurses and midwives who have good knowledge instead have practices that are not a good care for HIV patients. This is in line with research Adebajo (2003) which stated that there is no relation between the knowledge of nurses with HIV patient care practices. Angkawijaya's research (2016) showed that there is no significant relation between the level of knowledge and the prevention of hypertension in Motoboi Kecil Village. South Kotamobagu District with a value of $\mathrm{p}=1.0>0.05$. Prihanti et al. (2018) also said that there was no relation between the level of education with clean and healthy living behavior (PHBS) in the household structure in the work area of the Puskesmas Poned X. Good knowledge does not guarantee that it has good application. Therefore. counseling is needed to increase knowledge and awareness of safe behavior.

The absence of a significant relation between knowledge and safe behavior in informal sector workers in Karangwangkal causes the need to increase knowledge and awareness. especially for workers who are wellinformed. Knowledgeable female workers need to be educated and given information back about safe behavior for better health and well-being through increased productivity and income. This can be done through K3 counseling. Research by Ristiyanto et al. (2013) said that distributing leaflets. installing billboards and distributing posters can increase awareness to take disease prevention measures. In addition. Qadire and Khalaileh (2013) said that health education can improve nurses' knowledge and attitudes in pain management. A research by Fitriani (2013) found that knowledge about the potential dangers of contact dermatitis can be increased through providing information using leaflet media. The results showed that subjects given treatment had high knowledge scores compared to those who were not.

Table 8 shows that the majority of informal sector female workers in Karangwangkal have poor motivation and poor safe behavior. as many as 21 workers (46.7\%). 
Table 8. Results of Bivariate Analysis of Motivation with Safe Behavior of Informal Sector Female Workers in Karangwangkal, North Purwokerto

\begin{tabular}{llllllll}
\hline \multirow{2}{*}{$\begin{array}{l}\text { Work } \\
\text { Motivation }\end{array}$} & \multicolumn{2}{l}{ Safe Behavior } & Poor & & & Sig (p) & $\begin{array}{l}\text { Correlation } \\
\text { Coefficient } \\
\text { (r) }\end{array}$ \\
& $\mathrm{N}$ & Percentage (\%) & $\mathrm{N}$ & Percentage (\%) & Total & & \\
\hline Good & 4 & 8,9 & 17 & 37,8 & 21 & & \\
Poor & 3 & 6,6 & 21 & 46,7 & 24 & 0,545 & 0,366 \\
Total & 7 & 15,5 & 38 & 84,5 & 45 & & \\
\hline
\end{tabular}

However. as many as 17 workers $(37.8 \%)$ who had good work motivation. had poor safe behavior. The remaining 4 workers $(8.9 \%)$ have good work motivation and poor safe behavior and as many as 3 workers (6.6\%) have poor work motivation and good safe behavior. The results of the bivariate analysis using the chi square test showed a correlation value of 0.366 . This shows that there is a low level of relation between work motivation and safe behavior. Chi square analysis also showed that there was no significant relation between work motivation and safe behavior with a value of $p$ $=0.545>0.05$.

The absence of a relationship between work motivation and safe behavior is thought to be caused by the large number of female workers who have good work motivation but have poor safe behavior. Workers who have good work motivation but have poor safe behavior are thought to be caused by the lack of adequate facilities and infrastructure to conduct safe behavior. Female workers in the informal sector in Karangwangkal had a strong motivation to do safe behavior but did not have adequate facilities and infrastructure. The informal sector culinary and laundry female worker claimed not to have PPE such as gloves. aprons and masks. In addition. informal sector boarding-house female workers claimed not to clean the boarding-lodging kitchen because they did not have the time and energy. Workers do not employ others because of limited funds. This showed that informal female workers in Karangwangkal had a high workload. This is reinforced by Darmayanti's research (2016) showing that workers with high workloads in one Lampung hospital tend to not focus when working so that they behave insecently when working. This causes an increase in the level of errors when working. This is reinforced by the study of Chinanti and Siswati (2018) who said that high workloads caused a decrease in performance in workers in the shoe production department of PT Dwi Prima Sentosa Mojokerto. This makes workers in the production room unfocused because they are tired of working. behave insecure. and increase errors when working.

Kusgianto et al. (2017) said that there is a significant relation between workload and physical fatigue of workers. causing unsafe behavior and increasing work errors. This is affirmed by the study of Stevianingrum and Andhika (2016) which stated that the workload with work fatigue in Batik Brotoseno Marasan Sragen workers. In addition. research conducted by states that there is a significant relation between workload and work fatigue in workers in the melinjo chips industry in Benda Village Indramayu. This was confirmed by research by Wati and Haryono (2011) which showed that there was a significant relation between workload and work fatigue in laundry workers in the Warungboto sub-district. Umbulharjo District. Yogyakarta City. High workload caused an increase in pulse. A high pulse rate causes the worker's performance to improve and do a good job. However. along with the increasing activity with high workload and increased pulse rate. there is also a decrease in focus (concentration) when working due to reduced energy and increased physical fatigue (Kusgianto et al.. 2017). Physical recovery from fatigue due to high workload can be done with adequate rest and stretching. Each job completed for 4 hours requires a break of 30 minutes to heal fatigue due to monotonous work. Monotonous work exposure for a long time causes fatigue. decreased performance. 
work accidents. work-related illnesses. and job dissatisfaction. This can occur due to increased errors and decreased concentration at work (Ridley. 2008).

The insignificant relationship between motivation and safe behavior apart from being caused by workload. can also be caused by factors that can cause work fatigue in addition to workload. Wignjosoebroto (2003) said that there are factors that influence work fatigue and impact on unsafe behavior. namely environmental conditions. non-ergonomic environment. work monotony. psychology. emotions. illness. monotony. intensity. duration of work. working time. nutritional status. and health status.

Fitantri's research (2015) shows that facilities and infrastructure are factors that can affect motivation. Badminton athletes in Salatiga tend to have an increased motivation when badminton courts are added so that athletes do not queue for long periods when they want to practice. Long queues in the field due to many athletes who practice at same moment can make athletes experience boredom and burnout because they wait too long. Tobing research (2018) showed that there is no relation between motivation and maternal behavior in the utilization of BPJS in Tenanan Raya Health Center. Wahyudi et al. (2017) said that there is no relation between motivation and nurses caring behavior in the Sinjai Hospital Internal Care Room with a value of $\mathrm{p}=0.219>0.05$. This is because there are still many nurses who have low motivation to provide good service to patients.

Another thing that causes an insignificant relation between work motivation and safe behavior is the absence of reward. a feeling of dissatisfaction with the income received. lack of career advancement and a feeling of dissatisfaction with the work undertaken today (Halimah. 2010). Notoatmodjo (2009) said that reward or compensation as something that is received by workers as employee repayment for their work will increase the motivation of workers to work well because they get job satisfaction with the reward or compensation. This is in line with Sialagan (2008) which said that to realize safe behavior must be supported by conditions that facilitate safe behavior. High motivation that is not supported by facilities will only be a motivation not actualization. In addition. research by Helliyanti (2009) showed that there is no significant relation between work motivation and unsafe behavior. Endang's (2016) research showed that there is no relationship between work motivation and nurse performance.

Based on the discussion regarding there is no significant relation between knowledge and motivation with safe behavior in female workers in the informal sector in Karangwangkal above. it is expected to be a reference for further research to examine the factors that influence safe behavior in informal sector workers such as work duration. work time. nutritional status. health status. and emotions. Because this study gives insignificant results. the next researcher can discuss more factors that affect safe behavior with different research methods so that they can enrich new findings in the field of OHS. both of which later produce significant or insignificant results. Therefore. this research is important to be published.

\section{Conclussion}

Based on the results of the study. it can be concluded that there is no significant relation between knowledge and work motivation with safe behavior in informal sector female workers in Karangwangkal. North Purwokerto. Suggestions for further researchers is to add other variables that might affect safe behavior such as attitudes. perceptions. job satisfaction and support from colleagues.

\section{Acknowledgement}

Acknowledgments are addressed to LPPM UNSOED for providing funding for research. In addition. thank you to the Karangwangkal PKK organization. North Purwokerto and the UNSOED Public Health Information Technology Staff who have helped technical implementation of research in the field so that research can be done.

\section{Reference}

Agiviana. A.P.. \& Djastuti. I.. 2015. Analisis Pengaruh Persepsi. Sikap. Pengetahuan. dan Tempat Kerja terhadap Perilaku Keselamatan Karyawan. Diponegoro Journal of Management. 4(3): 1-9.

Adebajo S.B.. Bamgbala A.O.. Oyediran M.A.. (2003). Attitude of Health Care Providers to Persons Living With HIV/AIDS in Lagos 
State. Nigeria. African Journal of Reproductive Health. 7(1): pp. 103-112

Annishia. F.B.. 2011. Analisis Perilaku Tidak Aman Pekerja Konstruksi PT PP (Persero) di Proyek Pembangunan Tiffany Apartemen Jakarta Selatan Tahun 2011. Skripsi. Jakarta: FKIK UIN.

Azwar. S.. 2016. Sikap Manusia: Teori dan Pengukurannya. Yogyakarta: Pustaka Pelajar.

Badan Perencanaan Pembangunan Nasional. 2009. Peran Sektor Informal Sebagai Katup Pengaman Masalah Ketenagakerjaan. Jakarta: Badan Perencanaan Pembangunan Nasional.

Badan Pusat Statistik. 2018. Keadaan Ketenagakerjaan Indonesia Februari 2018. Jakarta: Badan Pusat Statistik.

Chinanti. D.W.P.. Siswati.. 2016. Hubungan Antara Kebahagiaan di Tempat Kerja dengan Keterikatan Karyawan pada PT Dwi Prima Sentosa Mojokerto. Jurnal Empati. 7(3): pp. 199-205.

Darmayanti. E.F.. 2016. Analisis Produktivitas Kerja Karyawan Dikaitkan dengan Time Management. AKUISISI. 12(1): 42-51.

Dzulfiqar. A.. \& Handayani. P.. 2016. FaktorFaktor yang Berhubungan dengan Perilaku Keselamatan pada Pekerja Bengkel Las di Wilayah Pejompongan Kelurahan Bendungan Hilir Jakarta Pusat. Jakarta: Universitas Esa Unggul.

Endang. T.. Nursalam. Nur. Q.. 2016. Kepemimpinan. Motivasi. dan Beban Kerja terhadap Kinerja Perawat dalam Pendokumentasian Asuhan Keperawatan. Jurnal INJEC. 1(1): pp. 90-95.

Fara. R.A.Z.. Kurniawan. B.. \& Wahyuni. I.. 2017. Faktor-Faktor yang Berhubungan dengan Safe Behavior pada Pekerja Rekanan Bagian Sipil di PT Indonesia Power Up Semarang. Jurnal Kesehatan Masyarakat. 5(5): pp. 318326.

Fatima. T.. 2015. Pengaruh Penyuluhan Gizi Seimbang dengan Media Video. Poster. dan Permainan Kwartet Gizi terhadap Pengetahuan Gizi dan Status Gizi Siswa di Sekolah Dasar Negeri Karang Asem. Surakarta: Universitas Negeri Surakarta.

Febrianti. S.. \& Musadieq. A.. 2014. Pengaruh Reward dan Punishment terhadap Motivasi Kerja serta Dampaknya terhadap Kinerja (Studi pada Karyawan PT Bank Panin Tbk Area Mikro Jombang). Jurnal Administrasi Bisnis. 12(1): pp. 1-9.

Fitriani. A.. 2013. Pengaruh Intervensi Penyuluhan Menggunakan Media Leaflet terhadap Perubahan Pengetahuan Mengenai
Potensi Bahaya Dermatitis Kontak dan Pencegahannya pada Pekerja Cleaning Service UI Syarif Hidayatullah Jakarta Tahun 2013. Naskah Publikasi. Jakarta: UIN Syarif Hidayatullah.

Fitriani. S.. 2011. Promosi Kesehatan. Yogyakarta: Graha Ilmu.

Fitranti. M.N.R.. (2015). Pengaruh Kelengkapan Sarana dan Prasarana dalam Memotivasi Atlet Bulutangkis untuk Berprestasi di Kota Salatiga. Universitas Negeri Semarang: Semarang.

Fuadi. F.I.. 2016. Hubungan antara Pengetahuan dengan Sikap Masyarakat dalam Mencegah Leptospirosis di Desa Pabelan Kecamatan Kartasura Kabupaten Sukoharjo. Naskah Publikasi. 1(1): pp. 1-8.

Geller. \& Scott. E.. 2005. Behavior Based Safety and Occupational Risk Management in Behavior Modification. Sage Publication. 29(3): pp. 539-561.

Green. 1980. Health Education: A Diagnosis Approach. The John Hopkins University: Mayfield Publishing Co.

Halimah.S.. 2010. Faktor-Faktoryang Mempengaruhi Perilaku Aman Karyawan di Area Produksi PT SIM Plant Tambun II Tahun 2010. Skripsi. Jakarta: FKIK UIN.

Hapsari. Y.D.. 2013. Hubungan antara Predisposing. Enabling. dan Reinforcing Factors dengan Unsafe Action (Studi di PT Waskita Karya (Persero) pada Proyek Pengembangan Bandara Internasional Juanda Surabaya. Skripsi. Surabaya: Universitas Airlangga.

Hart. K.. 1973. Informal Income Opportunities and Urban Employment in Ghana. Journal of Modern African Studies. 11(1): pp. 61-69.

Heinrich. H.W.. 1980. Industrial Accident Prevention. New York: Mc. Graw Hill Book Company.

Helliyanti. P.. 2009. Faktor-Faktor yang Berhubungan dengan Perilaku Tidak Aman di Departemen Utility and Operation PT Indofood Sukses Makmur Tbk Divisi Bogasari Flour Mills Tahun 2009. Skripsi. Depok: Universitas Indonesia.

Huda. U.F. Sukmawati. A.. \& Sumertajaya. I.M.. 2016. Model Perilaku Keselamatan Kerja Karyawan pada Industri Berisiko Tinggi. Jurnal Manajemen Teknologi. 15(1): pp. 5166.

Karyani. 2005. Faktor-Faktor yang Berpengaruh pada Perilaku Aman (Safety Behavior) di Schlumberger Indonesia. Tesis. Depok: Universitas Indonesia.

Kementerian Kesehatan RI. 2011. Promosi Kesehatan di Daerah Bermasalah Kesehatan (Panduan 
bagi Petugas Kesehatan di Puskesmas). Jakarta: Kementerian Kesehatan RI.

Kementerian Kesehatan RI. 2019. Hidupkan Pos UKK Agar Pekerja Sektor Informal Tersentuh Layanan Kesehatan Kerja. Jakarta: Kementerian Kesehatan RI.

Khorvash. F.. Mohamadirizi. S.. Ataiee. B.. Khayamim. N.. \& Boroumandfar. Z.. (2014). The Relationship between Knowledge. Attitude. and Tendency to Care of HIV/ AIDS Patients among Nurses and Midwives. Working in General Hospitals and Health Care Centers of Isfahan University of Medical Sciences in 2013. J Midwifery Reprod Health. 2(4): pp. 246-252.

Kusgianto. W.. Suroto. Ekawati.. 2017. Analisis Hubungan Beban Kerja Fisik. Masa Kerja. Usia. dan Jenis Kelamin terhadap Tingkat Kelelahan Kerja pada Pekerja Bagian Pembuatan Kulit Lumpia di Kelurahan Kranggan Kecamatan Semarang Tengah. Jurnal Kesehatan Masyarakat. 5(5): 413-423.

Mangkunegara. \& Anwar. P.. 2009. Manajemen Sumber Daya Perusahaan. Bandung: PT Remaja Rosdakarya.

Nasrullah.M.. \&Suwandi. T..2014. Hubungan Antara Knowledge. Attitude. Practice Safe Behavior Pekerja dalam Upaya untuk Menegakkan Keselamatan dan Kesehatan Kerja. The Indonesian Journal of Occuopational Safety and Health. 3(1): pp. 82-93.

Nawawi. H.. 2005. Manajemen Sumber Daya Manusia untuk Bisnis yang Kompetitif. Yogyakarta: Gadjah Mada University Press.

Notoatmodjo.S.. 2003. Pendidikan dan Perilaku Kesehatan. Jakarta: Rineka Cipta.

Notoatmodjo. S.. 2010. Ilmu Perilaku Kesehatan. Jakarta. Rineka Cipta.

Notoatmodjo. S.. 2012. Promosi Kesehatan dan Perilaku Kesehatan. Jakarta: Rineka Cipta.

Prihanti. G.S.. Lista. D.A.. Habibi. R.. Arsinta. I.I.. Hanggara. S.P.. Galih. R.P.. Sinta. F.. 2018. Faktor-Faktor yang Mempengaruhi Tingkat Perilaku Hidup Bersih dan Sehat pada Tatanan Rumah Tangga di Wilayah Kerja Puskesmas Poned X. E Journal UMM Malang. 14(1): pp. 7-13.

Qadire. A.. Khalaileh. M.. 2013. Effectiveness of Educational Intervention on Jordanion Nurses Knowledge and Attitude Regarding Pain Management. British Journal of Medicine \& Medical Research. 4(7): 1460-1472.

Reason. J.T.. 1997. Managing The Risk of Organizational Accident. Inggris: Ashgate Publishing Ltd.
Retnani. N.D.. \& Ardyanto. D.. 2013. Analisis Pengaruh Activator dan Consequence terhadap Safety Behavior pada Tenaga Kerja di PT Pupuk Kalimantan Timur Tahun 2013. The Indonesian Journal of Occupational Safety and Health. 2(2): pp. 119-129.

Ridley. J.. 2008. Kesehatan dan Keselamatan Kerja (Ikhtisar). Jakarta: Erlangga.

Ristiyanto. Heriyanto. Handayani. Trapsilowati. Pujiati \& Nugroho.. 2013. Studi Pencegahan Penularan Leptospirosis di Daerah Persawahan Kabupaten Bantul. Daerah Istimewa Yogyakarta. Jurnal Vektora 5(1).

Sary. I.A.P.. 2010. Upaya Promosi Kesehatan di Tempat Kerja Terkait Pengetahuan. Sikap. dan Perilaku Bagi Staf UI Tahun 2010. Tesis. Depok: Universitas Indonesia.

Sialagan. T.. 2008. Analisis Faktor-Faktor yang Berkontribusi pada Perilaku Aman di PT EGS Indonesia Tahun 2008. Tesis. Depok: Universitas Indonesia.

Stevianingrum. Andhika.. 2016. Hubungan Status Gizi dan Beban Kerja terhadap Kelelahan Kerja pada Pekerja Batik Brotoseno Marasan Sragen. Surakarta: Universitas Negeri Sebelas

Suci. R.. Restuatuti. T.. \& Fatmawati. 2012. Hubungan Pengetahuan dan Sikap Petugas Laboratorium Patologi Klinik terhadap Penerapan Standard Operating Procedure (SOP) Penanganan Bahan Infeksius di RSUD Arifin Achmad Provinsi Riau. Jom Fakultas Kedokteran. 1 (2): pp. 1-11.

Suizer. A.B.. 1999. Safety Behavior: Fewer Injuries. Jakarta: Balai Pustaka.

Suryadilaga. R.M.. Musadieq. M.A.. \& Nurtjahjono. G.E.. 2016. Pengaruh Reward dan Punishment terhadap Kinerja (Studi pada Karyawan PT Telkom Indonesia Witel Jatim Selatan Malang. Jurnal Administrasi Bisnis. 39(1): pp. 156-163.

Tobing. S.I.B.L.. 2015. Faktor-Faktor yang Berhubungan dengan Perilaku Ibu Bersalin dalam Pemanfaatan BPJS di Puskesmas Tenanan Raya. Jurnal Endurance. 3(1): pp. 25-32.

Wahyudi. Sutria. E.. Ashar. M.U.. Syisnawati.. 2017. Faktor-Faktor yang Berhubungan dengan Perilaku Caring Perawat di Ruang Perawatan Interna. Journal of Islamic Nursing. 2(2): pp. 83-92.

Wati. M.. Haryono. W.. 2011. Hubungan Antara Beban Kerja dengan Kelelahan Kerja Karyawan Laundry di Kelurahan Warungboto Kecamatan Umbulharjo Kota Yogyakarta. KES MAS. 5(3): 162-232.

Wibowo. S.. \& Suryani. D.. 2013. Pengaruh Promosi 
Suryanto, Damairia Hayu Parmasari / Knowledge and Motivation with Safe Behavior of Informal Sector Female Worker

Metode Audio Visual dan Metode Buku Saku terhadap Peningkatan Pengetahuan Penggunaan Monosodium Glutamat (MSG) pada Ibu Rumah Tangga. Yogyakarta: Universitas Ahmad Dahlan.

Wignjosoebroto. S.. 2003. Ergonomi Studi Gerak dan Waktu Teknik Analisis untuk Peningkatan Produktivitas Kerja. Surabaya: Guna Widya.
Zatalini. D.S.. \& Wulandari. D.R.. 2018. Pengaruh Penyuluhan dengan Metode Diskusi. Poster. dan Video terhadap Tingkat Pengetahuan Tentang Penyakit Menular Seksual pada Anak Jalanan Kota Semarang (Studi Kasus di Rumah Pintar Bang Jo). Jurnal Kedokteran Diponegoro. 7(2): pp. 442-450. 